\title{
Electro-removal of copper, chromium, and arsenic from chromated copper arsenate treated waste wood
}

\author{
Eletro-remoção de cobre, cromo e arsênico de resíduos \\ de madeira tratada com arseniato de cobre cromado
}

\section{Rodrigo José de Castro ${ }^{\oplus}$, Gustavo Delmar Kehl', Luana Candaten ${ }^{\circledR}$, Germana Davila dos Santos ${ }^{3}$, Paulo Roberto Bairros da Silva** ${ }^{1 *}$, Rômulo Trevisan' ${ }^{\circledR}$, Arci Dirceu Wastowski ${ }^{\circledR}$}

\begin{abstract}
Wood is a renewable material considered eco-friendly and used for various purposes. While wood treated with chromated copper arsenate (CCA) does not deteriorate, its final disposal may entail risks due to the concentration and toxicity of the components. The removal of CCA from wood can be achieved in different ways. This study focuses on the reduction of the concentrations of $\mathrm{Cu}, \mathrm{Cr}$, and As chemical species by the electro-removal technique, aiming to obtain biomass with low deleterious potential that would allow multiple uses or safe disposal in landfills. The analytical results showed reductions of $79.5,87.4$, and $81.3 \%$ in the mean concentrations of $\mathrm{Cu}, \mathrm{Cr}$, and As, respectively. It is worth mentioning the occurrence of the fungus Xylaria sp. after treatment 6 (60 min, $5 \mathrm{~g}$, and $25 \mathrm{~V}$ ), further suggesting that the method was effective. Samples of these fungi were identified from isolates by culture in medium, DNA extraction, and sequencing of the Internal Transcribed Spacer (ITS) region.
\end{abstract}

Keywords: environmental risk; solid waste; chemical species; dispersive energy $\mathrm{x}$-ray fluorescence spectrometry.

\section{RESUMO}

A madeira é um material renovável, considerado ecologicamente correto e utilizado para diversos fins. Embora a madeira tratada com arseniato de cobre cromado (CCA) não se deteriore facilmente, seu descarte final pode acarretar riscos devido à concentração e toxicidade dos componentes. A remoção do CCA da madeira pode ser realizada de diferentes maneiras. Este estudo teve como foco a redução das concentrações de espécies químicas $\mathrm{Cu}, \mathrm{Cr}$ e As pela técnica de eletro-remoção, visando obter uma biomassa com baixo potencial deletério que permitiria múltiplos usos ou disposição final segura em aterros sanitários. Os resultados analíticos mostraram reduções de 79,5; 87,4 e 81,3\% nas concentrações médias de $\mathrm{Cu}, \mathrm{Cr}$ e As, respectivamente. Vale ressaltar a ocorrência do fungo Xylaria sp. após o tratamento 6 ( 60 min, 5 g e 25 V), sugerindo ainda que o método foi eficaz. Amostras desses fungos foram identificadas dos isolados por meio de cultura em meio, extração de DNA e sequenciamento da região do espaçador transcrito interno (ITS)

Palavras-chave: risco ambiental; resíduo sólido; espécies químicas; espectrometria de fluorescência de raios x por energia dispersiva.

\section{INTRODUCTION}

Considered to be an environment friendly material for several purposes, wood has an organic, natural, and renewable origin. In addition, wood has a hydrophobic biological constitution and hydrophilic fibers, giving it physical-mechanical properties that differentiate it from other materials (MOHAJERANI; VAJNA; ELLCOCK, 2018; FERNÁNDEZ-COSTAS et al., 2017; VIDAL et al., 2015).
However, wood has the disadvantage of being prone to deterioration and its durability is closely related to its service life when exposed to abiotic factors, such as variations in temperature, humidity, luminosity, and acidity of the soil or xylophagous organisms, such as bacteria, fungi, mollusks, crustaceans, and insects, which also act on their environmental degradation (MOHAJERANI; VAJNA; ELLCOCK, 2018; BOTOMÉ et al., 2017; CHAGAS et al., 2015).

'Universidade Federal de Santa Maria - Santa Maria, (RS), Brazil.

2Universidade de São Paulo - São Paulo (SP), Brazil.

${ }^{3}$ Universidade Federal do Paraná - Curitiba (PR), Brazil.

*Corresponding author: paulo.bairros-silva@ufsm.br

Conflicts of interest: the authors declare no conflicts of interest. Funding: Conselho Nacional de Desenvolvimento Ciêntífico e Tecnológico (CNPq)

Received: 07/15/2019 - Accepted: 12/16/2O19 - Reg. ABES: 20190319 
In order to avoid deterioration and provide an extension to its useful life, wood is subjected to treatments with chemical preservatives, especially watersoluble preservatives composed of a combination of water-soluble salts (BABAEE; MULLIGAN; RAHAMAN, 2018; OHGAMI et al., 2015; MERCER; FROSTICK, 2014). Chromated copper arsenate (CCA) provides an insecticidal and fungicidal action when applied to the wood. It is currently considered to be the most efficient wood preservative, acting mainly on the permeable outer layers of wood and blocking deterioration by chemical, physical, and biological agents (FERNÁNDEZ-COSTAS et al., 2017; BOTOMÉ et al., 2017; VIDAL et al., 2015).

However, concerns due to the high toxicity of the mixture of inorganic compounds with copper, chromium, and arsenic base, together with the possibility of leaching causing deleterious effects on the environment, led to the prohibition of CCA by countries such as the USA, England, Denmark, and Canada (OHGAMI et al., 2015; MERCER; FROSTICK, 2014; JANIN et al., 2012).

In Brazil, the Brazilian Institute of the Environment and Renewable Natural Resources (Instituto Brasileiro do Meio Ambiente e dos Recursos Naturais Renováveis -Ibama) allows the industrial use of the CCA with the formulation based on salt contents of chromium (45.7\%), copper (18.5\%), and arsenic (34. 0\%), which is classified as CCA type C (CHAGAS et al., 2015; OHGAMI et al., 2015; VIDAL et al., 2015). Brazil consumes approximately $700,000 \mathrm{~m}^{3} /$ year of treated wood, a large part of which comes from plantations of eucalyptus (93.5\%) and pine (6.5\%). Most of this wood is treated with CCA and applied in the production of stakes (62\%), poles (30\%), railroad ties (5\%), and in civil construction (3\%), demonstrating that CCA represents an excellent commercial alternative to increase the durability of wood (FERRARINI et al., 2016; VIDAL et al., 2015; FERRARINI et al., 2015).

When removed from service life, a large proportion of copper $(\mathrm{Cu})$, chromium (Cr), and arsenic (As) remains in treated wood and can enter the waste stream unless actions are taken to avoid it (FDEP, 2017; TANG et al., 2015; OHGAMI et al., 2015).

After its use, CCA-treated wood generates waste categorized in class I - hazardous, according to the Brazilian Association of Technical Standards (Associação Brasileira de Normas Técnicas - ABNT, 2004), NBR 10004, whose objective is to classify solid waste according to their potential risks to the environment and to public health so that they can be properly managed. The solid and semi-solid residues resulting from anthropogenic activities, including the liquid effluents and debris originated from the wood preservation process, must be subjected to treatments with economically viable techniques and good removal efficiency so they can be discarded in class II - non-hazardous landfill sites.

The final disposal of CCA-treated wood becomes a challenge to the environmental sciences as it is a solid residue with high concentrations of $\mathrm{Cu}, \mathrm{Cr}$, and As, which are toxic components with possible harmful interactions with local communities (MOHAJERANI; VAJNA; ELLCOCK, 2018; FDEP, 2017; OHGAMI et al., 2015). Incineration of those wastes is prohibited in many countries, such as Denmark and Brazil, and may pose a risk to human health (FERNÁNDEZCOSTAS et al., 2017; BOTOMÉ et al., 2017; OHGAMI et al., 2015).

Although the specialized literature points to studies on wood preservatives that are less aggressive to the environment, there are currently no efficient and economically viable substitutes in relation to CCA, whose consumption should continue to increase in the coming decades (MOHAJERANI; VAJNA; ELLCOCK, 2018; VIDAL et al., 2015; FERRARINI et al., 2015). In Brazil, there is no regulation targeted at the disposal of these solid residues, and one of the current challenges is the removal of CCA from treated wood for reuse or recycling (FERRARINI et al., 2016; VIDAL et al., 2015; FERRARINI et al., 2015).

According to the National Solid Waste Policy, Law Number 12.305/2010, waste management has the objective of protecting public health and environmental quality, whose responsibility falls on generators and public authorities (BRASIL, 2012). As stated by D'Almeida and Vilhena (2000), the management of solid waste, including its treatment and final disposal, is the responsibility of generators.

Therefore, it is important to develop methodologies for the removal of toxic elements in those types of waste, predicting the difficulties related to their use and proposing viable alternatives for reuse or disposal (SANTOS et al., 2018; TANG et al., 2015; FERRANI et al., 2015). Numerous researchers have turned their attention to the efficacy and use of electro-removal processes in CCA-treated wood compounds as well as avoiding the possible contamination of soils and water from the use of discarded CCA-treated wood at the end of its service life (FDEP, 2017; KUMPIENE et al., 2016; OHGAMI et al., 2015; FERRARINI et al., 2015).

Studies in the last decades have shown concern over the remediation of CCA-treated wood by the use of different extractive solvents, such as oxalic acid, phosphoric acid, sulfuric acid, EDTA, hydrogen peroxide, and their mixture in different proportions (MOHAJERANI; VAJNA; ELLCOCK, 2018; KUMPIENE et al., 2016; FERRARINI et al., 2015; JANIN et al., 2012). Janin et al. (2012) show that the best cost-benefit ratio lies in the use of sulfuric acid-based electrolytic extractive solutions, but state that oxalic acid has a higher extraction yield when compared to EDTA, phosphoric acid, or sulfuric acid alone. There is also a great interest in the development of effluent recovery technologies resulting from these extractive treatments through techniques, such as coagulation/precipitation with ferric chlorides, route-evaporation of compounds, and exchange of ions through ion exchange membranes (BABAEE; MULLIGAN; RAHAMAN, 2018; FERRARINI et al., 2016; COUDERT et al., 2014; JANIN et al., 2012).

The electro-removal technique is based on the emergence of an electric field in a conductive solution created by a voltage source between the electrode terminals. The electromotive force acting between the terminals of the graphite electrodes through the action of the voltage source constitutes an electric field capable of polarizing the CCA salts. This is achieved by the production of polarization voltages between the molecules and also with the acid electrolytic conductive medium, guiding the movement of ions in the solution and "pulling" the CCA from the wood (TICIANELLI; GONZALEZ, 2015; BRETT; BRETT, 2000). The reactions involved in the electron translation process are:

$\mathrm{CuO}+\mathrm{C}_{2} \mathrm{H}_{2} \mathrm{O}_{4} \leftrightarrow 2 \mathrm{CO}_{2}+\mathrm{H}_{2} \mathrm{O}+\mathrm{Cu}$

$\mathrm{K}_{2} \mathrm{Cr}_{2} \mathrm{O}_{7}+\mathrm{C}_{2} \mathrm{H}_{2} \mathrm{O}_{4} \leftrightarrow \mathrm{H}_{2} \mathrm{Cr}_{2} \mathrm{O}_{7}+\mathrm{K}_{2} \mathrm{C}_{2} \mathrm{O}_{4}$ $\mathrm{As}_{2} \mathrm{O}_{3}+2 \mathrm{H}_{3} \mathrm{PO}_{4} \leftrightarrow \mathrm{P}_{2} \mathrm{O}_{3}+2 \mathrm{H}_{3} \mathrm{AsO}_{4}$

This electric field is capable of mediating an electric force on the ions of the system, which provides electrokinetic movement (MERCER; FROSTICK, 2014; COUDERT et al., 2014; CHRISTENSEN et al., 2006). Thus, the cleaning agent used in the electro-removal process is provided by an electric current that transports the soluble ions $(\mathrm{Cu}, \mathrm{Cr}$, and $\mathrm{As})$ that are present in the wood (SANTOS et al., 2018; MOHAJERANI; VAJNA; ELLCOCK, 2018; FERRARINI et al., 2016; TANG et al., 2015; CHRISTENSEN et al., 2006).

Energy dispersive X-ray fluorescence (EDXRF) is one of the techniques recommended by the American Association of Environmental Impact Researchers 
for Treated Wood, at the Bill Hinkley Center for Solid and Hazardous Waste Management, for quality-quantification of CCA in wood samples (FDEP, 2017). Furthermore, several studies use EDXRF for the quantification of compounds in the wood (BARATA et al., 2013; COL; BUENO, 2009; SOLO-GABRIELE et al., 2004).

In this sense, the electro-turning technique should not be confused with the process of adsorption of metals in liquid medium by sawdust of wood since it deals precisely with the process of removal of $\mathrm{Cu}, \mathrm{Cr}$, and As metals from wood treated with CCA. The metals removed from the wood (solid material) pass into an electrolytic fluid and can be used again in the production of CCA for the preservation of new wood or to be recovered from the medium by different methods (BABAEE; MULLIGAN; RAHAMAN, 2018; FERRARINI et al., 2016; TANG et al., 2015; JANIN et al., 2012).

In this context, the objective of this study is to investigate the electroremoval of $\mathrm{Cu}, \mathrm{Cr}$, and As from CCA-treated wood waste by an electro-removal technique, aiming at the formation of biomass with low deleterious potential that allows multiple uses of the material or even its safe disposal in landfills.

\section{METHODOLOGY}

\section{Protocol of clean techniques and preparation of solutions}

Clean technique protocols were adopted for the cleaning of glassware and the preparation of storage containers. These were treated in Extran (10\%, $24 \mathrm{~h})$, triple washed with distilled water (Quimis $\left.{ }^{\circledR}, \mathrm{Q} 341-25\right)$, bathed with nitric acid (10\%, $24 \mathrm{~h}$ ), and triple washed with ultrapure water. In accordance with the cleaning techniques protocol, the samples and other materials were manipulated in a granite worktop after being cleaned in order to minimize the effects of possible contaminations by chemical species according to the clean techniques protocol.

All reagents used were of analytical grade, and ultrapure water was used for the preparation of solutions (Millipore equipment, Simplicity - UV).

\section{Collection and reparation of samples}

The samples destined for the electro-removal treatment were obtained from a public lighting pole donated by the Procel Company of the Frederico Westphalen City. The CCA-treated wood from Eucalyptus grandis has been in use for over 20 years for electric power transmission lines. With the aid of an electric chain saw (Electric chain $2200 \mathrm{~W}$ Saber $18 " 45 \mathrm{~cm}$ - Tekna) the material was fractionated into smaller parts and sent to the joinery, where the chip reduction $(<2 \mathrm{~cm}$ in length) was performed with the aid of an equipment for shredding organic waste (Trapp brand, TR 200 model), as recommended by Christensen et al. (2006).

Parts of these samples were sent directly to perform the electro-removal process in different experimental conditions according to the factorial design. The remainder were stored in a double Ziplock $(2 \mathrm{~L})$ polypropylene bag, identified with labels (external/internal) made in pencil, and sent for further quantification of the average concentrations of the chemical species of interest.

\section{Electro-removal treatments}

The electro-removal treatment system used in this study was mounted on the bench scale (Figure 1) and operated through the use of a voltage source (Ametek, Sorensen, XPD 120-4.5). During the experiment, different electrical potentials

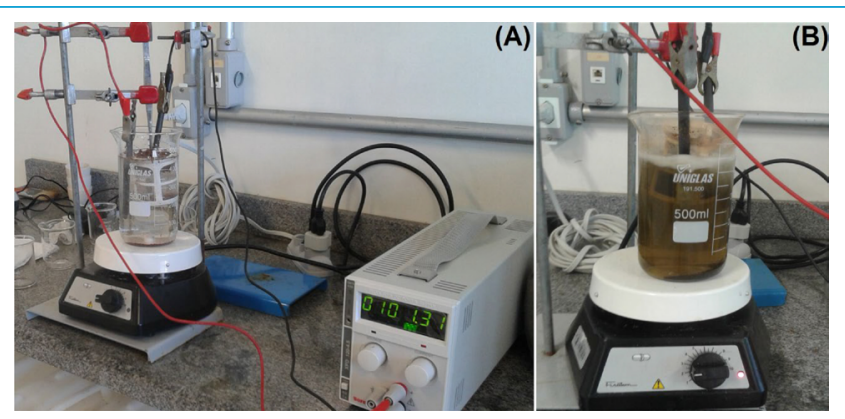

Source: prepared by the authors (2019)

Figure 1- Detail of the electro-removal experiment: $(A)$ initial state of the treatment system, (B) final state after the treatment system.

were applied between the electrode terminals of graphite immersed in an electrolytic conducting solution, between which some mass of CCA-treated wood was deposited. Graphite was chosen as the base material of the conduction electrodes because it is an excellent conductive material to use in electrodes, it is cheap when compared to other types of materials and it also enables the reuse of the electrode without the loss of its capacity (MANOSSO, 2006).

The base of the system was formed by a magnetic stirrer that provided smooth movement of the electrolytic conductive solution in order to avoid excessive heating during the treatment. This study opted for the formulation proposed by Christensen et al. (2006), a mixture of oxalic acid and phosphoric acid, which is considered the one with the highest extraction yield.

For each test, samples were prepared in volumes of $450 \mathrm{~mL}$ using ultrapure water, $150 \mathrm{~mL}$ of oxalic acid at $5 \%$ concentration, and $300 \mathrm{~mL}$ of phosphoric acid at a concentration of $0.5 \mathrm{~mol} \mathrm{~L}^{-1}$. Separate batches of wood samples were packed in a porous polypropylene filter system aligned between the terminals in order to prevent the free dispersion of the sample in the conductive solution.

\section{Quantification of $\mathrm{Cu}, \mathrm{Cr}$, and As concentrations}

Two control samples were obtained by the mechanical pruning of branches using a metal blade (machete), with a diameter greater than 50 and $250 \mathrm{~mm}$ in length, of a tree from the Eucalyptus grandis forest in the Universidade Federal de Santa Maria (UFSM) area. These were taken to the laboratory, where they were devoid of the internal and external peels and dried in a circulation oven at $50^{\circ} \mathrm{C}$ for $120 \mathrm{~h}$. They were then fragmented into powder fractions (sawdust) and sent to mechanical screening in a sieve agitator system, with only fine fractions $(<0.063 \mathrm{~mm}$ ) being used as white control (without CCA) and in production of reference material in this study.

For the analysis, data were taken in triplicate, with samples of $1 \mathrm{~g}$ of mass. Samples were fragmented in a knife mill equipment (Solab brand, SL 31 model), sieved in a mechanical sieve agitator system (Edutec brand, EEQ9029A model) for the separation of fine fractions $(<0.063 \mathrm{~mm})$, and supported on a sample port (31 mm Closed X-Cell - SPEX) with thin film (Mylar, $6 \mu$-SPEX). Materials from the white samples (1 $\mathrm{g}$ mass; in fine fractions) were used as a reference, doped with $1 \mathrm{~mL}$ of Fluka brand ICP spectroscopic multi-element standard solution at concentrations of $50 \pm 0.2 \mathrm{mg} \mathrm{L}^{-1}$ for chromium and $10 \pm 0.04 \mathrm{mg} \mathrm{L}^{-1}$ for copper. Then, $1 \mathrm{ml}$ of an Arsenic solution prepared at the concentration of 
$63.5 \pm 2.7 \mathrm{mg} \mathrm{L}^{-1}$ was added following the dissolution of $2.095 \mathrm{mg}$ of analytical standard reagent $\mathrm{As}_{2} \mathrm{O}_{3}$ (Vetec brand) in $2 \mathrm{ml}$ of ultra-pure nitric acid (Merck label) and a $25 \mathrm{~mL}$ flask with aliquots of ultrapure water.

The fine fractions doping was deposited in the sample holder and dried in a circulation oven $\left(40^{\circ} \mathrm{C}, 72 \mathrm{~h}\right)$ to ensure the solution penetration into the wood fibers. The quantification of the mean concentrations of $\mathrm{Cu}, \mathrm{Cr}$, and As chemical species was performed before and after the electro-removal treatment in an $\mathrm{X}$-ray spectrometer by dispersive energy (Shimadzu brand, EDX-720 model), allowing the comparison of the results.

The operating conditions were: X-ray tube: $\mathrm{Rh} 3 \mathrm{~kW}$, excitation: $15 \mathrm{kV}$ for $\mathrm{Si} \mathrm{Ka}$ and $50 \mathrm{kV}$ for UL $\alpha$, collimator: $10 \mathrm{~mm}$, detector: $\mathrm{Si}$ ( $\mathrm{Li}$ ) cooled with liquid nitrogen, and integration time: $100 \mathrm{~s}$. Simultaneous data collection in the wood samples was performed using the Fundamental Parameters Method (YOUNIS et al., 2017; ROUSSEAU, 2013), with 15 retrievals of the reference standard to establish the mean analytical figures of merit, standard deviation, precision by determining the coefficient of variance (\%), accuracy by determination of relative error (\%), limit of determination of the method, and Z-Score test (INMETRO, 2018; SILVA et al., 2016).

\section{Experimental planning, statistical analysis, and graphic constructions}

A factorial scheme depends, in part, on the range of factors investigated. Thus, differences at levels large enough to cause alterations in the responses were defined, allowing the evaluation of the experimental error (BARROS NETO; SCARMINIO; BRUNNS, 2001). The values of electrical voltage, treatment time, and mass of CCA treated wood were varied in order to allow an experimental arrangement by a factorial design $2^{3}$, which allowed identifying the ideal operating conditions for the system. In addition, values inconsistent with the reality of the experimental apparatus were avoided, since they would make data acquisition impossible. Table 1 presents the experimental factors and the levels used in the study.

For data analysis and the creation of graphics, the open-source multi-platform SciDAVis software was used (BENKERT; FRANKE; STANDISH, 2007) The ANOVA and Tukey's pairwise test were performed in the PAST software, version 3.08 (HAMMER; HARPER; RYAN, 2001). The results of the study of the relationship between factors, levels, and interactions associated with the different treatments are presented in Table 2.

Table 1 - Factors and levels used in experimental planning.

\begin{tabular}{l|c|c}
\multirow{2}{*}{ Factors } & \multicolumn{2}{|c}{ Levels } \\
\cline { 2 - 3 } & $(-)$ & $(+)$ \\
1. Time (minutes) & 20 & 60 \\
\hline 2. Mass (grams) & 5 & 15 \\
\hline 3. Voltage (Volts) & 10 & 25 \\
\hline
\end{tabular}

Source: prepared by the authors (2019)

Table 2 - Factorial planning of electro-removal of $\mathrm{Cr}$, $\mathrm{Cu}$ and $\mathrm{As}$ from CCA treated wood

\begin{tabular}{|c|c|c|c|c|c|c|c|}
\hline Treatment & Factor 1 & Factor2 & Factor 3 & R1 & R2 & R3 & $\mathrm{Rm}$ \\
\hline (Chrome) & (Time) & (Mass) & (Voltage) & $\left(\mathrm{mg} \mathrm{kg}^{-1}\right)$ & $\left(\mathrm{mg} \mathrm{kg}^{-1}\right)$ & $\left(\mathrm{mg} \mathrm{kg}^{-1}\right)$ & $\left(\mathrm{mg} \mathrm{kg}^{-1}\right)$ \\
\hline 1 & - & - & - & 61.6 & 64.1 & 71 & 65.6 \\
\hline 2 & + & - & - & 81.9 & 60.9 & 72.8 & 71.9 \\
\hline 3 & - & + & - & 66.3 & 89.3 & 82.1 & 79.2 \\
\hline 4 & + & + & - & 38.6 & 39.2 & 49.1 & 42.3 \\
\hline 5 & - & - & + & 40.5 & 42.5 & 39 & 40.7 \\
\hline 6 & + & - & + & 13.7 & 17 & 17 & 15.9 \\
\hline 7 & - & + & + & 17.4 & 16.3 & 18 & 17.2 \\
\hline 8 & + & + & + & 16.4 & 16.6 & 16.7 & 16.6 \\
\hline \multicolumn{8}{|l|}{ (Copper) } \\
\hline 1 & - & - & - & 27 & 27.8 & 28.2 & 27.6 \\
\hline 2 & + & - & - & 31.4 & 24.7 & 29 & 28.4 \\
\hline 3 & - & + & - & 32.3 & 41.7 & 39 & 37.7 \\
\hline 4 & + & + & - & 18.2 & 18 & 20.3 & 18.8 \\
\hline 5 & - & - & + & 15.5 & 16.1 & 15.1 & 15.6 \\
\hline 6 & + & - & + & 10.3 & 13 & 13 & 12.1 \\
\hline 7 & - & + & + & 15 & 15.1 & 16.3 & 15.5 \\
\hline 8 & + & + & + & 21.4 & 30.9 & 15.7 & 22.7 \\
\hline \multicolumn{8}{|l|}{ (Arsenic) } \\
\hline 1 & - & - & - & 89.8 & 101.1 & 119.1 & 103.3 \\
\hline 2 & + & - & - & 131.9 & 95.8 & 102.3 & 110 \\
\hline 3 & - & + & - & 105.1 & 130.3 & 134.3 & 123.2 \\
\hline 4 & + & + & - & 82 & 66.3 & 81.7 & 76.7 \\
\hline 5 & - & - & + & 34.9 & 51.9 & 42.4 & 43.1 \\
\hline 6 & + & - & + & 15.8 & 20.4 & 20.8 & 19 \\
\hline 7 & - & + & + & 32.5 & 42 & 32.9 & 35.8 \\
\hline 8 & + & + & + & 33.6 & 39.3 & 35 & 36 \\
\hline
\end{tabular}

R1, R2, R3: Concentrations of Cr / Cu / As (Triplicate); RM: Mean concentrations of Cr / Cu / As

Source: prepared by the authors (2019). 


\section{Identification of the fungal isolate}

It is worth mentioning that the onset of the fungus Xylaria sp. in the samples occurred after treatment $6(60 \mathrm{~min}, 5 \mathrm{~g}, 25 \mathrm{~V})$ and $7(20 \mathrm{~min}, 15 \mathrm{~g}, 25 \mathrm{~V})$, suggesting that the method may be effective. The methodology for extracting DNA from isolates was described by Vicente et al. (2008).

The material was triturated and chloroform was added. The aqueous phase was collected, transferred to a new tube, and had ethanol added to precipitate the DNA. The DNA obtained was quantified by spectrophotometry $(260 \mathrm{~nm})$ and its integrity verified in $0.8 \%$ agarose gel.

Amplicons were purified with Exonuclease I and Alkaline Phosphatase (SAP) and sequenced using a BigDye Terminator Cycle Sequencing Kit v. 3.1 (Applied Biosystems, Foster City, CA, USA), according to the manufacturer's instructions. Reactions were purified with Sephadex G-50 (GE Healthcare BioSciences, Uppsala, Sweden) and the sequences were analyzed in an ABI Prism 3,500 DNA Sequencer (Perkin-Elmer, Norwalk, Foster City, CA, USA). The sequences obtained were edited with the BioEdit software (HALL, 1999) and compared to the reference sequences in the GenBank (Supplementary Material) datasets. The alignment was performed with MAFFT (KATOH et al., 2005) and visual inspection was performed with the MEGA v7 software (KUMAR; STECHER; TAMURA, 2016). The best evolutionary model for each dataset was estimated using MEGA v7. A phylogenetic tree was constructed with 1,000 bootstrap replicates using the maximum probability method implemented in Mega v7.

\section{RESULTS AND DISCUSSION}

\section{Analytical figures of merit and mean concentrations of analytes obtained by dispersive energy $x$-ray fluorescence spectrometry}

The EDXRF technique was demonstrated to meet the requirements of the analytical applications according to the merit figures, ensuring the reliability of the results for the $\mathrm{Cu}, \mathrm{Cr}$, and As chemical species. Table 3 shows the results of the mean, confidence interval, precision CV (\%), error (\%), the determination limit of the method (DML), and the Z-Score test obtained from data on the standard sample.

The results presented in Table 3 show a good agreement between the material's reference and tracing, and also point to the precision of the chemical species analysis by the EDXRF technique, which was inferior to $20 \%$, an acceptable standard for environmental samples (INMETRO, 2018). The error was estimated to be less than $10 \%$, while the limit of determination of the method

Table 3 - Analytical figure of merit of the process of taking data by EDXRF.

\begin{tabular}{c|c|c|c|c|c|c} 
Analyte & $\begin{array}{c}\mathrm{MR} \\
\left(\mathrm{mg} \mathrm{kg}^{-1}\right)\end{array}$ & $\begin{array}{c}x \\
\left(\mathrm{mg} \mathrm{kg}^{-1}\right)\end{array}$ & $\mathrm{CV}(\%)$ & $\mathrm{E}(\%)$ & $\mathrm{DML}$ & Z-score \\
$\mathrm{Cu}$ & $10 \pm 0.04$ & $10.1 \pm 0.3$ & 3.4 & 0.6 & 0.3 & 0.1 \\
\hline $\mathrm{Cr}$ & $50 \pm 0.2$ & $52.8 \pm 1.7$ & 6.4 & 5.7 & 8.9 & 0.8 \\
\hline As & $63.5 \pm 2.7$ & $63.1 \pm 1.6$ & 4.9 & -0.7 & 4.5 & -0.1 \\
\hline
\end{tabular}

EDXRF: energy dispersive X-ray fluorescence; MR: reference material; : mean concentrations in the reference sample; CV: precision; E: error; DML: determination limit of the method; Z-SCORE: Z-Score test.

Source: prepared by the authors (2019). was compatible with the mean concentrations of the chemical species in the reference material (INMETRO, 2018; ROUSSEAU, 2013).

\section{Experimental planning of the electro-removal technique}

The best treatment for the removal of the chemical element chromium (Table 2) was the sixth treatment, which was performed with the longer time (60 min), the lower mass (5 g), and the higher electrical voltage between the terminals ( 25 $\mathrm{V})$. This treatment resulted in an mean concentration of $15.9 \mathrm{mg} \mathrm{kg}^{-1}$, providing greater removal of chromium than the control (mean concentration of 124.1 $\mathrm{mg} \mathrm{kg}^{-1}$ ), i.e., a reduction of $87.2 \%$ over the initial concentration. The eighth electro-removal treatment, performed with the use of the longest time factor ( $60 \mathrm{~min}$ ), the greatest mass ( $15 \mathrm{~g}$ ), and the highest voltage between the terminals $(25 \mathrm{~V})$, provided an average after-removal concentration of $16.6 \mathrm{mg} \mathrm{kg}^{-1}$. Finally, the seventh electro-removal treatment, performed with the shortest time $(20 \mathrm{~min})$, the greatest mass $(15 \mathrm{~g})$, and the highest tension $(25 \mathrm{~V})$, reduced the mean concentration to $17.2 \mathrm{mg} \mathrm{kg}^{-1}$.

For $\mathrm{Cu}$, it is highlighted that the seventh electro-removal treatment presented a mean concentration of $15.6 \mathrm{mg} \mathrm{kg}^{-1}$ after the treatment (Table 2). The treatment had shorter applied time (20 min), lower mass $(5 \mathrm{~g})$, and higher tension between the terminals $(25 \mathrm{~V})$. In relation to the control, the best electro-removal treatment for copper was the sixth. This treatment used the greatest time factor ( $60 \mathrm{~min}$ ), the smallest mass $(5 \mathrm{~g})$, and the highest voltage between the terminals $(25 \mathrm{~V})$ and resulted in a mean concentration of $12.1 \mathrm{mg} \mathrm{kg}^{-1}$ in the treated wood, leading to a greater copper removal than the control (mean concentration of $59.1 \mathrm{mg} \mathrm{kg}^{-1}$ ), i.e., a reduction of $79.5 \%$ in relation to the initial concentration.

The highest reduction of mean arsenic concentration in the samples (Table 2) was evidenced in the seventh treatment, which used the lowest time factor (20 $\mathrm{min})$, the largest mass (15 $\mathrm{g}$ ), and the highest voltage between the terminals $(25 \mathrm{~V})$. This treatment resulted in a mean concentration of $35.8 \mathrm{mg}$ $\mathrm{kg}^{-1}$ in the treated wood, providing greater removal of arsenic than the control (mean concentrations of $191 \mathrm{mg} \mathrm{kg}^{-1}$ ), i.e., a reduction of $81.3 \%$ relative to the initial concentration.

Thus, the electro-removal process proved to be more advantageous, mainly due to the use of graphite electrodes, which are low-cost materials and have a much shorter process time. These results corroborate those of Christensen et al. (2006) who, in electro-dialysis experiments under different conditions, obtained the removal of $87 \%$ of $\mathrm{Cu}, 81 \%$ of $\mathrm{Cr}$, and $95 \%$ of As by means of electrolytic membranes and platinum electrodes. Pedersen et al. (2005), working on a smallscale pilot plant, found reductions of $82 \%$ of $\mathrm{Cr}, 88 \%$ of $\mathrm{Cu}$, and $96 \%$ of As after 21 days of an electro-dialysis treatment with ion-exchange membranes in a glass chamber and platinum electrodes. In a 30-day treatment experiment, Ribeiro et al. (2000) obtained yields of CCA removal from treated wood in the order of $93 \%$ for $\mathrm{Cu}, 95 \%$ for $\mathrm{Cr}$, and $99 \%$ for As due to process optimization of experimental conditions with the use of membranes and ion-exchange electrodes.

The factorial design shows that the treatment conditions for $\mathrm{Cu}$, using greater time, lower mass, and higher tension obtained a better agreement, with a mean of $15.9 \mathrm{mg} \mathrm{kg}^{-1}$. The best treatment for $\mathrm{Cr}$, also due to the factors mentioned above, obtained a mean of $12.1 \mathrm{mg} \mathrm{kg}^{-1}$. For As, the best conditions were also represented by greater time, lower mass, and higher tension. Considering these results, it can be concluded that the treatment conditions of the sixth electroremoval treatment were ideal for the removal of $\mathrm{Cu}, \mathrm{Cr}$, and $\mathrm{As}$. 
Figure 2 shows the efficiency of the electro-removal treatment for the removal of $\mathrm{Cu}(\mathrm{A}), \mathrm{Cr}(\mathrm{B})$, and $\mathrm{As}(\mathrm{C})$ chemical species in relation to the control samples. The most effective removals were observed in the $20 \mathrm{~min}, 5 \mathrm{~g}$, and $25 \mathrm{~V} ; 20 \mathrm{~min}, 15 \mathrm{~g}, 2 \mathrm{~V}$; and $60 \mathrm{~min}, 5 \mathrm{~g}, 25 \mathrm{~V}$ conditions for $\mathrm{Cu}(\mathrm{A}), \mathrm{Cr}(\mathrm{B})$, and As, respectively, all related to treatment 6.

In addition, the study emphasizes the efficiency of the electro-removal treatment of chemical species by reducing $\mathrm{Cu}$ (by more than four times in the best treatment in relation to the untreated control), $\mathrm{Cr}$ (by more than five times in the best treatment in relation to the untreated control), and As (by more than ten times in the best treatment in relation to the untreated control). The ANOVA test (Table 4) demonstrates the existence of significant differences $(p<0.05)$ between the different treatments when considering each chemical species in relation to the untreated sample.

\section{Electro-removal post-treatment biological responses}

After the wood samples dried out in the circulation oven, it was observed that the formation of fungi occurred in treatment 6 , a fact that may be associated with a biological response to the greater efficiency of this treatment in the removal of highly toxic elements present in the samples. Figure 3 shows the formation of fungi in the samples (image taken with a manual microscope; Wireless Microscope, magnification of 50-500x).

Based on the sequence analysis of the internal transcribed spacer (ITS) regions of the rDNA gene, it was possible to identify the isolated fungus Xylaria $\mathrm{sp}$. This region is widely used for the identification of fungi because it is highly intra-specifically conserved but variable among different species, which makes it possible to distinguish it at the specific level (FUNGARO, 2000; MORESCHI, 2013). The phylogenetic tree was constructed by the Maximum Probability method implemented with the standard Kimura 2-parameter model. The proportion of completely indeterminate gaps and characters in this alignment was 0.22 , with 33 distinct alignment patterns. The frequencies of the empirical basis were pi (A): 0.231, $\mathrm{Pi}(\mathrm{T}): 0.231, \mathrm{Pi}(\mathrm{C}): 0.299$, and $\mathrm{Pi}(\mathrm{G}): 0.269$ with 1,000 bootstrap replicates.
Table 4 - Anova test applied to the data of each of the treatments of electroremoval.

\begin{tabular}{|c|c|c|c|c|}
\hline & \multicolumn{4}{|c|}{ CHROME } \\
\hline & Sum of sqrs & $D F$ & $F$ & $p$ \\
\hline Between groups & $31,530.8$ & 8 & 84.3 & $1.1 \times 10^{-12}$ \\
\hline Within groups & 841.847 & 18 & & \\
\hline \multirow[t]{3}{*}{ Total } & $32,372.7$ & 26 & & \\
\hline & \multicolumn{4}{|c|}{ COPPER } \\
\hline & Sum of sqrs & $D F$ & $F$ & $p$ \\
\hline Between groups & $5,136.3$ & 8 & 42.2 & $4.2 \times 10^{-18}$ \\
\hline Within groups & 273.9 & 18 & & \\
\hline \multirow[t]{3}{*}{ Total } & $5,410.2$ & 26 & & \\
\hline & \multicolumn{4}{|c|}{ ArseniC } \\
\hline & Sum of sqrs & $D F$ & $F$ & $p$ \\
\hline Between groups & $73,761.2$ & 8 & 50.8 & $8.7 \times 10^{-11}$ \\
\hline Within groups & $3,267.41$ & 18 & & \\
\hline Total & 7,7028.6 & 26 & & \\
\hline
\end{tabular}

$d$ : degrees of freedom; F: statistics; $p$ : probability.

Source: prepared by the authors (2019).

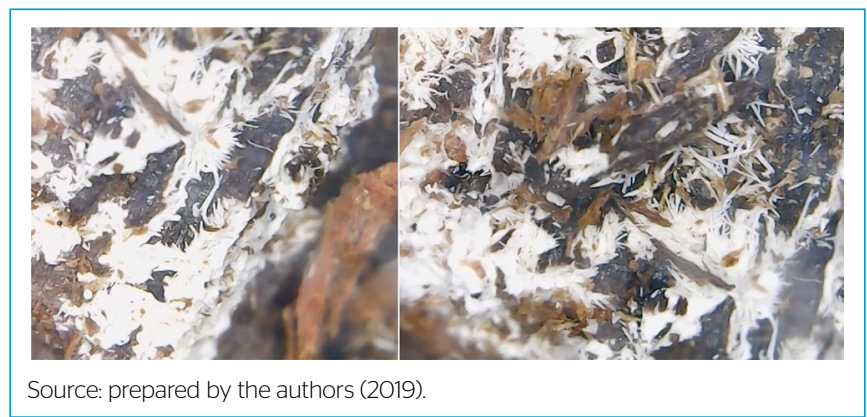

Figure 3 - Formation of fungi.

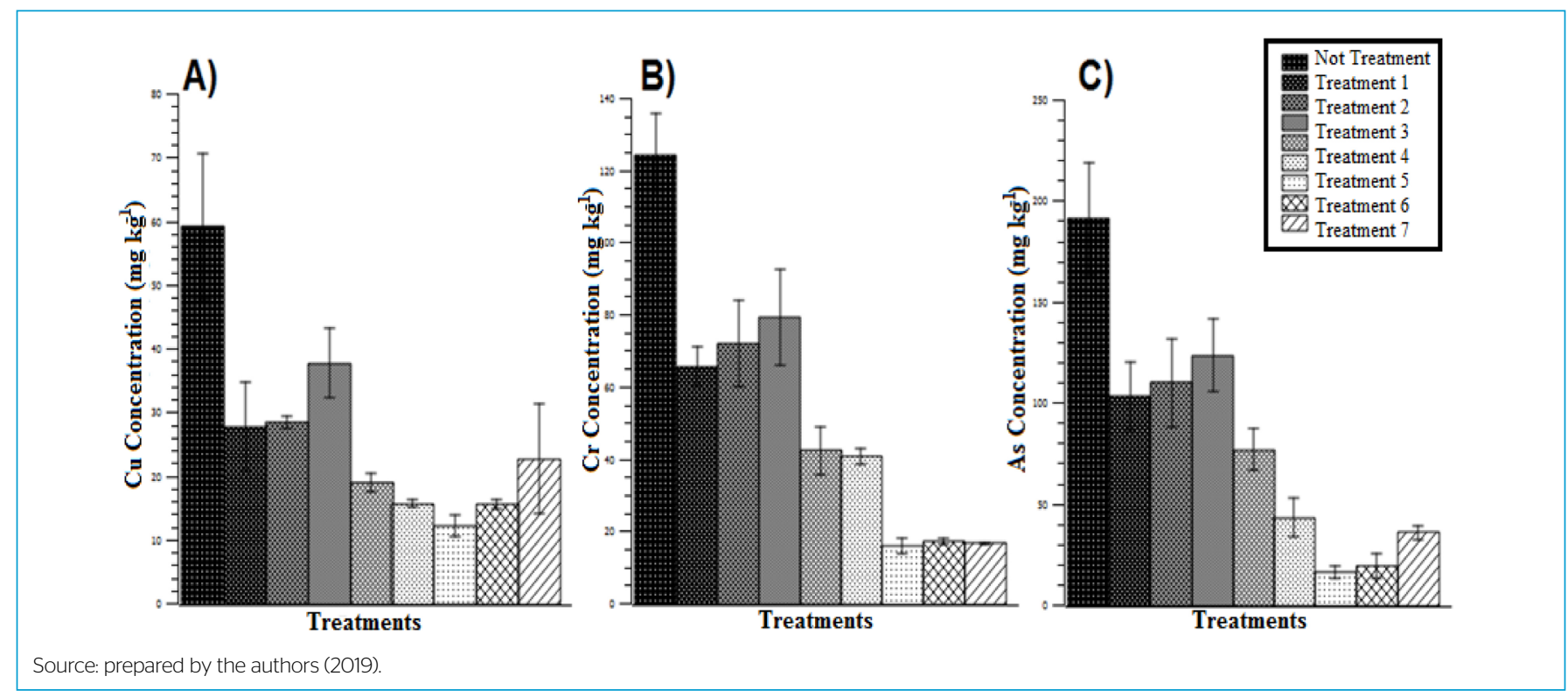

Figure 2 - Mean concentrations of (A) Cu, (B) $\mathrm{Cr}$, and (C) As in the wood samples. 
The Xylariaceae family is the largest of the Ascomycota phylum, comprising 86 genera, seven of which are uncertain, and more than 1,343 species (LUMBSCH; HUHNDORF, 2010; STADLER et al., 2013). In Brazil, 24 generic names, 213 specific epithets, and 10 infra-specifics ones were listed (PEREIRA, 2015). Members of Xylariaceae play a functional role in terrestrial ecosystems, decomposing a wide range of substrates such as wood, leaves, seeds, and fruits. The great majority live as saprophytes soon after tree deaths, while other species act as phytopathogenic and endophytic (ROGERS, 1979; WHALLEY, 1985).

Included in the order Sphaeriales and the family Xylariaceae, Xylaria is classified as a white-rot fungus due to the degradation of the lignin present in the chemical constitution of the wood. It can sometimes be described as soft rot, requiring concise macroscopic and microscopic analyses and chemical characteristics to define the type of degradation.

In general, Xylaria sp. has been described as wood-degrading due to its habit of colonizing decomposing material and/or living as saprophytes of woody plants (ALEXOPOULOS; MIMS; BLACKWELL, 1996). As a general characteristic, the fungi of the species Xylaria sp. have black and rough clavulated stromas, with a diameter and length ranging from 2 to $5 \mathrm{~mm}$ and 5 to $7 \mathrm{~cm}$, respectively, simple or branched, and sooty and white dotted surfaces.

\section{CONCLUSIONS}

The best $\mathrm{Cr}$ removal conditions were obtained with the highest stress, lowest mass, and longest time ( $60 \mathrm{~min}, 5 \mathrm{~g}$, and $25 \mathrm{~V})$ of treatment. After the treatment, a contaminated chemical residue composed of $\mathrm{Cu}, \mathrm{Cr}$, and As is generated. This residue can be processed for its reuse in the form of CCA preservative, which allows the restart of the treatment cycle of the wood.
Electro-removal, including the use of alternative materials that provide good results, produced reductions in $\mathrm{Cu}, \mathrm{Cr}$, and As mean concentrations of $79.5,87.4$, and $81.3 \%$, respectively, than in other techniques commonly used for the removal of CCA. The electro-removal of the CCA preservative present in treated wood proved to be technically feasible. The results showed the proliferation of the fungus Xylaria sp. in the wood samples from treatment six, as well as the satisfactory removal of chemical species from the wood.

This study could represent the basis for other studies aiming to develop a pilot plant that could allow the study of the best treatments for larger amounts of CCA-treated wood.

\section{ACKNOWLEDGMENTS}

The authors are very grateful for the contributions made by the biologist Andrea Giovenardi of Universidade Federal de Santa Maria, Campus Frederico Westphalen, for the loan and use of the manual digital microscope.

\section{AUTHORS' CONTRIBUTIONS}

Castro, R. J.: Formal Analysis, Investigation, Writing - Original Draft. Kehl, G. D.: Formal Analysis, Investigation, Writing - Original Draft. Candaten, L.: Investigation, Writing - Original Draft. Santos, G. D.: Data Curation, Formal Analysis, Investigation, Software, Validation, Writing - Original Draft. Silva, P. R. B.: Conceptualization, Data Curation, Formal Analysis, Investigation, Methodology, Project Administration, Software, Supervision, Validation, Visualization, Writing - Original Draft, Writing - Review \& Editing. Trevisan, R.: Investigation, Writing - Original Draft. Wastowski, A. D.: Funding Acquisition, Resources.

\section{REFERENCES}

ALEXOPOULOS, C.J.; MIMS, C.W.; BLACKWELL, M. Introductory Mycology. New York: John Wiley \& Sons, 1996.

BABAEE, Y.; MULLIGAN, C.N.; RAHAMAN, M.S. Arsenic immobilization in soil using starch-stabilized Fe/Cu nanoparticles: a case study in treatment of a chromated copper arsenate (CCA)-contaminated soil at lab scale. Journal of Soils and Sediments, v. 18, p. 1610-1619, 2018. https://doi. org/10.1007/s11368-017-1882-2

BARATA, C.; CARBALlO, J.; CRUZ, A.J; COROADO, J.; ARAÚJO, M.E.; MENDONÇA, M.H. Caracterização através de análise química da escultura portuguesa sobre madeira de produção erudita e de produção popular da época barroca. Química Nova, v. 36, n. 1, p. 21-26, 2013. https://doi.org/10.1590/ S0100-40422013000100005

BARROS NETO, B.; SCARMINIO, I.S.; BRUNNS, R.E. How to vary everything at the same time. In: How to do experiments: research and development in science and industry. Campinas: Editora da Unicamp, 2001.

BENKERT, T.; FRANKE, K.; STANDISH, R. SciDAVis. 2007. Available at: http:// scidavis.sourceforge.net/. Accessed on: Oct. 21, 2018.

BOTOMÉ, M.L.; POLETTO, P.; JUNGES, J.; PERONDI, D.; DETTMER, A.; GODINHO, M. Preparation and characterization of a metal-rich activated carbon from CCA-treated wood for $\mathrm{CO}_{2}$ capture. Chemical Engineering Journal, v. 321, p. 614-621, 2017. https://doi.org/10.1016/j.cej.2017.04.004

BRASIL. National Policy on Solid Waste. 2. ed. Law 12.305 of 2010. Brasil, 2012. BRAZILIAN ASSOCIATION OF TECHNICAL STANDARDS (ABNT). NBR 10004: Brazilian Standard for the classification of solid waste. Rio de Janeiro: ABNT, 2004.

BRETT, A.M.O:; BRETT, C.M.A. Electroquímica: princípios, métodos e aplicações. Brasil: Almedina Brasil, 2000

CHAGAS, S.F.; EVANGELISTA, W.V.; SILVA, J.C.; PINHEIRO, M.A. Study of the retention and penetration of CCA in teakwood, for use as treated fence posts. Scientia Forestalis, v. 43, n. 105, p. 155-165, 2015

CHRISTENSEN, I.V.; PEDERSEN, A.J.; OTTOSEN, L.M.; RIBEIRO, A.B Electrodialytic remediation of CCA-treated waste wood in a $2 \mathrm{~m}^{3}$ pilot plant. Science of the Total Environment, v. 364, n. 1-3, p. 45-54, 2006. https://doi. org/10.1016/j.scitotenv.2005.11.018

COL, J.A.; BUENO, M.I.M.S. Emprego da fluorescência de raios X por dispersão para o mapeamento de troncos de árvores em Campinas, São Paulo. Química Nova, v.32,n. 9. p. 2407-2411,2009.https://doi.org/10.1590/S0100-40422009000900032 
COUDERT, L.; BLAIS, J.F.; MERCIER, G.; COOPER, P.; JANIN, A.; GASTONGUAY, L. Demonstration of efficiency and robustness of an acid leaching process to remove metals from various CCA-treated wood samples. Journal of Environmental Management, v. 132, p. 197-206, 2014. https://doi.org/10.1016/j. jenvman.2013.11.028

D’ALMEIDA, M.L.O.; VILHENA, A. Municipal waste: Integrated management manual. $2^{2}$ ed. IPT/CEMPRE: São Paulo, 2000

FERNÁNDEZ-COSTAS, C.; PALANTI, S.; CHARPENTIER, J.P.; SANROMÁN, M.A.; MOLDES, D. A sustainable treatment for wood preservation: enzymatic grafting of wood extractives. ACS Sustainable Chemistry \& Engineering, v. 5, n. 9. p. 7557-7567, 2017. https://doi.org/10.1021/acssuschemeng.7b00714

FERRARINI, S.F.; MIRANDA, L.G.; MAIA, S.M.; PIRES, M. Chromated copper arsenate (CCA) treated wood: destination options for waste generated and perspectives in the development de methodologies for toxic elements removal. Periódico Tchê Química, v. 12, n. 23, p. 7-21, 2015.

FERRARINI, S.F.; SANTOS, H.S.; MIRANDA, L.G.; AZEVEDO, C.M.; MAIA, S.M.; CHAVES, E.S.; PIRES, M. Determination of $\mathrm{As}$, $\mathrm{Cr}$, and $\mathrm{Cu}$ Concentrations in CCA-treated Wood Poles Using Acid Decomposition in Closed Flasks, Oven Heating, and ICP-MS Analysis. Atomic Spectroscopy, v. 36, n. 5, p. 187-195, 2015.

FERRARINI, S.F.; SANTOS, H.S.; MIRANDA, L.G.; AZEVEDO, C.M.N.; MAIA, S.M.; PIRES, M. Decontamination of CCA-Treated eucalyptus Wood waste by acid leaching. Waste Management, v. 49, p. 253-262, 2016. https://doi. org/10.1016/j.wasman.2016.01.031

FLORIDA DEPARTMENT OF ENVIRONMENT PROTECTION (FDEP). Guidance for the management and disposal of CCA-treated wood. FDEP, 2017.

FUNGARO, M.H.P. PCR na micologia, diagnóstico e análise de variabilidade. Biotecnologia, Ciência \& Desenvolvimento, Brasília, v. 17, p. 12-16, 2000.

HALL, T.A. BioEdit: a user-friendly biological sequence alignment editor and analysis program for windows. Nuclide Acids, v. 41, p. 95-98, 1999.

HAMMER, Ø.; HARPER, D.A.T.; RYAN, P.D. PAST: Paleontological statistics software package for education and data analysis. Palaeontologia Electronica, v. 4, n. 1, p. 1-9, 2001.

JANIN, A.; COUDERT, L.; BLAIS, J.F.; MERCIER, G.; COOPER, P.; GASTONGUAY, L.; MORRIS, P. Design and performance of a pilot-scale equipment for CCAtreated wood remediation. Separation and Purification Technology, v. 85, p. 90-95, 2012. https://doi.org/10.1016/j.seppur.2011.09.052

KATOH, K.; KUMA, K.; TOH, H.; MIYATA, T. MAFFT version 5: improvement in accuracy of multiple sequence alignment. Nucleic Acids Res, v. 33, n. 2, p. 511-518, 2005. https://doi.org/10.1093\%2Fnar\%2Fgki198

KUMAR, S.; STECHER, G.; TAMURA, K. MEGA7: molecular evolutionary genetics analysis version 7.0 for bigger datasets. Molecular Biology and Evolution, v. 33, n. 7. p. 1870-1874, 2016. https://doi.org/10.1093/molbev/msw054

KUMPIENE, J.; NORDMARK, D.; HAMBERG, R.; CARABANTE, I.; SIMANAVICIENÉ, R.; AKSAMITAUSKAS, V.C. Leaching of arsenic, copper and chromium from thermally treated soil. Journal Environmental Management, v. 183, part 3, p. 460-466, 2016. https://doi.org/10.1016/j.jenvman.2016.08.080

LUMBSCH, H.T.; HUHNDORF, S.M. Outline of Ascomycota-2009. Notes on Ascomycete Systematics Myconet, v. 14, n. 1, p. 1-64, 2010. https://doi. org/10.3158/1557.1
MANOSSO, H.C. Electrochemical ion exchange electrodes development for the treatment of wastes containing chromium or cesium ions. $85 \mathrm{f}$ Thesis (Doctoring Program) - Nuclear and Energy Research Institute, Universidade de São Paulo, São Paulo, 2006.

MERCER, T.G.; FROSTICK, L.E. Evaluating the potential environmental pollution from chromated copper arsenate (CCA)-treated wood waste: a new mass balance approach. Journal of Hazardous Material, v. 276, p. 10-18, 2014. https://doi.org/10.1016/j.jhazmat.2014.05.006

MOHAJERANI, A.; VAJNA, J.; ELLCOCK, R. Chromated copper arsenate timber: a review of products leachate studies and recycling. Journal of Cleaner Production, v. 179, p. 292-307, 2018. https://doi.org/10.1016/j. jclepro.2018.01.111

MORESCHI, J.C. Biodegradation and preservation of wood. Curitiba, 2013. v.1. Available at: www.madeira.ufpr.br/disciplinasmoreschi/BIODETERIORACAO pdf. Accessed on: Oct. 7, 2018

NATIONAL INSTITUTE OF METROLOGY, QUALITY AND TECHNOLOGY (INMETRO). Guidance on Validation of Analytical Methods. São Paulo: General Coordination of Accreditation of São Paulo, Inmetro, 2018.

OHGAMI, N.; YAMANOSHITA, O.; THANG, N.D.; YAJIMA, l.; NAKANO, C.; WENTING, W.; OHNUMA, S.; KATO, M. Carcinogenic risk of chromium, copper and arsenic in CCA-treated wood. Environmental Pollution, v. 206 p. 456-460, 2015. https://doi.org/10.1016/j.envpol.2015.07.041

PEDERSEN, A.J.; KRISTENSEN, V.; OTTOSEN, L.M.; RIBEIRO, A.B. VILLUMSEN, A. Electrodialytic remediation of CCA-treated waste wood in pilot scale. Engineering Geology, v. 77, n. 3-4, p. 331-338, 2005. https://doi. org/10.1016/j.enggeo.2004.07.023

PEREIRA, J. Xylariales list of species of the flora of Brazil. Rio de Janeiro: Botanical Garden of Rio de Janeiro, 2015. Available at: http://floradobrasil. jbrj.gov.br/jabot/floradobrasil/FB121078. Accessed on: Oct. 7, 2018

RIBEIRO, A.B.; MATEUS, E.P.; OTTOSEN, L.M.; BECH-NILSEN, G. Electrodialytic Removal of $\mathrm{Cu}, \mathrm{Cr}$, and As from Chromated Copper ArsenateTreated Timber Waste. Environmental Science and Technology, v. 34, n. 5, p. 784-788, 2000. https://doi.org/10.1021/es990442e

ROGERS, J.D. Xylaria magnolia sp. nov. and comments on several other fruit-inhabiting species. Canadian Journal of Botany, v. 57, n. 8, p. 941-945, 1979. https://doi.org/10.1139/b79-115

ROUSSEAU, R. How to apply the fundamental parameters method to the quantitative $x$-ray fluorescence analysis of geological materials. Journal of Geosciences and Geomatics, v. 1, n. 1, p. 1-7, 2013. https://doi.org/10.13140/ RG.2.1.4333.2561

SANTOS, H.S.; FERRARINI, S.F.; FLORES, F.Q.; PIRES, M.J.R.; AZEVEDO, C.M.N.; COUDERT, L.; BLAIS, J.F. Removal of toxic elements from wastewater generated in the decontamination of CCA-treated Eucalyptus sp. and Pinus canadense wood. Journal of Material Cycles and Waste Management, v. 20, n. 1, p. 1299-1309, 2018. https://doi.org/10.1007/s10163-017-0694-1

SILVA, P.R.B.; MAKARA, C.N.; MUNARO, A.P.; SCHINITZLER, D.C. WASTOWISKI, A.D.; POLETO, C. Comparison of the analytica performance of EDXRF and FAAS techniques in the determination of metal species concentrations using protocol 3050B (USEPA). International Journal River Basin Management, v. 14, n. 4, p. 401-406, 2016. https://doi.org/10.1080/15715124.2016.1203792 
SOLO-GABRIELE, H.M.; TOWNSEND, T.G.; HAHN, D.W.; MOSKAL, T.M.; HOSEIN, N.; JAMBECK, J.; JACOBI, G. Evaluation of XRF and LIBIS technologies for on-line sorting of CCA-treated wood waste. Waste Management, v. 24, n. 4, p. 413-424, 2004. https://doi.org/10.1016/j. wasman.2003.09.006

STADLER, M.; KUHNERT, E.; PERSOH, D.; FOURNIER, J. The Xylariaceae as model example for a unified nomenclature following the "One Fungus-One Name" (1F1N) concept. Mycology, v. 4, n. 1, p. 5-21, 2013.

TANG, Y.; GAO, W.; WANG, X.; DING, S.; AN, T.; XIAO, W.; WONG, M.H.; ZHANG, C. Variation of arsenic concentration on surfaces of in-service CCA-treated wood planks in a park and its influencing field factors. Environmental Monitoring and Assessment, v. 187, n. 1, p. 4214, 2015. https://doi.org/10.1007/ s10661-014-4214-7

TICIANELLI, E.A.; GONZALEZ, E.R. Eletroquímica: princípios e aplicações. São Paulo: Edusp, 2015. 232 p.
VICENTE, V.A.; ATTILI-ANGELIS, D.; PIE, M.R.; QUEIROZ-TELLES, F.; CRUZ, L.M.; NAJAFZADEH, M.J.; HOOG, G.S.; ZHAO, J.; PIZZIRANI-KLEINER, A Environmental isolation of black yeast-like fungi involved in human infection. Studies in Mycology, v. 61, p. 137-144, 2008. https://doi. org/10.3114\%2Fsim.2008.61.14

VIDAL, J.M.; EVANGELISTA, W.V.; SILVA, J.C.; JANKOWSKY, I.P. Wood preservation in Brazil: historical, current scenario and trends. Ciência Florestal, v. 25, n. 1, p. 257-271, 2015. https://doi.org/10.1590/1980509820152505257

WHALLEY, A.J.S. The Xylariaceae: some ecological considerations. Sydowia, v. 38, p. 369-382, 1985

YOUNIS, A.; Ahmadi, Z:; Adams, A.G.; lqbal, A. A simple method for quantitative analysis of elements by XRF using variable dilution factors in fusion bead technique for geologic specimens. X-Ray Spectrometry, v. 46, n. 1, p. 69-76, 2017. https://doi.org/10.1002/xrs.2729 